\title{
Growth and Nutritional Status of Passiflora edulis f. Flavicarpa, With the Application of Organic Compound in Amazonian Soil
}

\author{
Sávia P. da Silva ${ }^{2}$, Ismael de J. M. Viégas ${ }^{2}$, Jessivaldo R. Galvão ${ }^{1}$, Heraclito E. O. da Conceição ${ }^{3}$, \\ Dioclea A. S. Silva ${ }^{2}$, Tiago K. M. Yakuwa ${ }^{1}$, Merilene do S. S. Costa ${ }^{1}$, Jhonatah A. Gomes ${ }^{2}$, \\ Camila N. Sagais ${ }^{2}$, Sharon E. B. Raiol ${ }^{2} \&$ Jorge C. Azevedo $^{1}$ \\ ${ }^{1}$ Universidade Rural da Amazônia, Belém, Pará, Brazil \\ ${ }^{2}$ Universidade Rural da Amazônia, Campus Capanema, Capanema, Pará, Brazil \\ ${ }^{3}$ Universidade Rural da Amazônia, Campus Capitão Poço, Capitão Poço, Pará, Brazil \\ Correspondence: Jessivaldo R. Galvão, Institute of Agricultural Sciences, Universidade Federal Rural da \\ Amazônia, Soil Department, Tancredo Neves, $N^{\circ}$ 2501, Montese, Belém, State of Pará, Brazil. Tel: \\ 55-919-8842-1133. E-mail: jessi.galvao50@gmail.com
}

Received: January 21, 2019

Accepted: April 20, $2019 \quad$ Online Published: June 30, 2019

doi:10.5539/jas.v11n9p52

URL: https://doi.org/10.5539/jas.v11n9p52

\begin{abstract}
Growth with organic fertilizers has increased in recent years because of the beneficial effect of organic matter on intensely cultivated soils and the high costs of mineral fertilizers. In order to evaluate the effects of organic compost doses produced from family farming waste on the growth and nutritional status of the passion fruit, an experiment was carried out in a greenhouse at the Universidade Federal Rural da Amazônia, in Belém, State of Pará, in the period from March to June, 2012. The experimental design was completely randomized, with five treatments and four replications, with each experimental plot made up by a pot with a volume of $3.6 \mathrm{dm}^{3}$ of soil and a yellow passion fruit seedling. Five doses of organic compost $(0 \%, 15 \%, 30 \%, 45 \%$, and $60 \%)$ were tested out of the total volume of the substrate. The compost was formed by mixing $10 \%$ poultry litter, $20 \%$ duck litter, $15 \%$ manioc husk, $15 \%$ cassava leaf, $15 \%$ bean straw, $15 \%$ rice husk, and $10 \%$ corn cob. The different amounts of organic compost were mixed in volumetric proportions of substrate of Yellow Latosol with a sandy texture, taken from the surface layer $(0-20 \mathrm{~cm})$. It was found that at 97 days, the best results were achieved at the dose of $60 \%$ of the compost. The content and accumulation of macronutrients in the foliar tissue of the yellow passion fruit plants followed this descending order: $\mathrm{K}>\mathrm{N}>\mathrm{Ca}>\mathrm{P}>\mathrm{Mg} \geq \mathrm{S}$.
\end{abstract}

Keywords: absorption of nutrients; growth; mineral nutrition; organic fertilization; Passiflora edulis

\section{Introduction}

The production of passion fruit has been gaining great importance in the world. In addition, Brazil is the world's largest producer and consumer (Garcia et al., 2011). According to Meletti (2011), passion fruit has been a prominent place in fruit growing, due to the soil and climatic conditions, as to the acceptance of its fruits for consumption in natura and for the fruit pulp industry. The country presented a production of 554,598 tons in 2017, where about $70 \%$ of the production comes from the Brazilian northeastern region (IBGE, 2017). The harvested area is 41,090 hectares, in which $95 \%$ are cultivated with yellow passion fruit ( $P$. edulis Sims f. flavicarpa Degener) and 5\% are cultivated with sweet passion fruit ( $P$. alata Dryander). The largest producers are the states of Bahia, Ceará, Santa Catarina, São Paulo and Rio Grande do Norte (IBGE, 2017). However, despite this prominent position in the domestic and international scenario, the domestic productivity of passion fruit is relatively small.

Passion fruit can be grown in almost all of the national territory, it occupies small areas, it has few manpower, making it an excellent option to improve family farming income, and an alternative to reduce costs is to replace or reduce the use of fertilizers minerals by organic fertilizers (Tenório et al., 2016).

Organic matter is fundamental for the maintenance of productive capacity in any terrestrial ecosystem. Physical point of view, improve soil structure, reduce plasticity and cohesion, increase water capacity and aeration, higher concentration of voice and root distribution. It acts on soil fertility, being a source of macro and micronutrients, to increase the capacity of cations exchange (Cunha et al., 2015). 
Studies on the extraction of nutrients by yellow passion fruit show that nitrogen, potassium and calcium are the most absorbed nutrients (Faleiro, 2016), with small variations in the order of nutrient uptake in works developed with the crop (Gondim, 2009).

The state of Pará holds a considerable amount of organic waste, among which cattle and poultry manure, industrial waste, manioc flowers among others, stand out. Therefore, the organic fertilization or even its association with mineral fertilization are alternatives for the producers in this region. Little is known about the effect of these organic materials on the growth and nutritional status of yellow passion fruit. Therefore, the objective of this work was to evaluate the growth and nutritional status of yellow passion fruit in a greenhouse using different doses of organic compost from the family farming in the municipality of Moju, state of Pará.

\section{Material and Methods}

\subsection{Experimental Site}

The experiment was conducted in a greenhouse at Institute of Agriculture Sciences at the Federal Rural University of the Amazon in Belém, state of Pará (Latitude $01^{\circ} 26^{\prime} 00^{\prime \prime} \mathrm{S}$; longitude $48^{\circ} 26^{\prime} 00^{\prime \prime} \mathrm{W}$; altitude of 10 $\mathrm{m}$ ), from March to June 2012, with an average annual temperature ranging from $27^{\circ} \mathrm{C}$ to $30^{\circ} \mathrm{C}$, with oscillations from $1{ }^{\circ} \mathrm{C}$ to $3{ }^{\circ} \mathrm{C}$ over the year.

\subsection{Soil Sampling and Analysis}

The different amounts of organic compost, consisting of $10 \%$ poultry litter, $20 \%$ duck litter, $15 \%$ cassava husk, $15 \%$ cassava leaf, $15 \%$ bean straw, $15 \%$ rice husk and $10 \%$ of corncob were mixed in volumetric proportions with the sandy textured Yellow Latosol, collected from the $0-20 \mathrm{~cm}$ layer of an area of secondary vegetation in the municipality of Moju (PA), Tracateua community. The organic compost was loosened, dried in the air and sieved through a 5-mm mesh screen. A sub-sample was taken, which was sieved through a 2-mm sieve, forming the air-dried fine earth (ADFE) for chemical and textural characterization.

For the determinations of clay, silt and sand content, the pipette method was used. The extractors used in the chemical analysis of soil samples were, as follows: for $\mathrm{P}, \mathrm{Na}, \mathrm{K}, \mathrm{Fe}, \mathrm{Zn}, \mathrm{Mn}$ and $\mathrm{Cu}$, Mehlich 1; for $\mathrm{Ca}, \mathrm{Mg}$ and $\mathrm{Al}$, $\mathrm{KCl} 1 \mathrm{~mol} \mathrm{~L}^{-1}$; for $\mathrm{H}+\mathrm{Al}, 0.5$ mols L${ }^{-1}$ calcium acetate, $\mathrm{pH}$ 7.0; for $\mathrm{B}$, hot water; for $\mathrm{S}$, monocalcium phosphate. The organic carbon (OC) was determined by the Walkley-Black method, following the methodology described by Empresa Brasileira de Pesquisa Agropecuária (Brazilian Agricultural Research Corporation), (1997).

Prior to the experiment set up, the results of the physical and chemical analysis of the soil were: physical characteristics: $481 \mathrm{~g} \mathrm{~kg}^{-1}$ of coarse sand, $336 \mathrm{~g} \mathrm{~kg}^{-1}$ of fine sand, $103 \mathrm{~g} \mathrm{~kg}^{-1}$ of silt and $80 \mathrm{~g} \mathrm{~kg}^{-1}$ of clay; and chemical characteristics: $\mathrm{pH}$ in $\mathrm{H}_{2} \mathrm{O}=6.2, \mathrm{~N}=0.13 \%$, extractable $\mathrm{P}=1 \mathrm{mg} \mathrm{dm}{ }^{-3}, \mathrm{~K}^{+}=0.11 \mathrm{cmolc} \mathrm{dm}^{-3}, \mathrm{Na}^{+}=$ $0.08 \mathrm{cmolc} \mathrm{dm}^{-3}, \mathrm{Ca}^{2+}=2.7 \mathrm{cmolc} \mathrm{dm}{ }^{-3}, \mathrm{Ca}^{2+}+\mathrm{Mg}^{2+}=3.6 \mathrm{cmol} \mathrm{dm}^{-3}, \mathrm{~S}=4.8, \mathrm{Al}^{3+}=0 \mathrm{cmolc} \mathrm{dm}^{-3}$. The micronutrients: $\mathrm{Zn}=1.50 \mathrm{mg} \mathrm{dm}^{-3}, \mathrm{Fe}=34.6 \mathrm{mg} \mathrm{dm}^{-3}, \mathrm{Mn}=16.8 \mathrm{mg} \mathrm{dm}^{-3}, \mathrm{~B}=0.39 \mathrm{mg} \mathrm{dm}^{-3}$ and $\mathrm{Cu}=2.0 \mathrm{mg}$ $\mathrm{dm}^{-3}$. Other soil analysis results: $\mathrm{H}+\mathrm{Al}=2.6 \mathrm{cmolc} \mathrm{dm}^{-3}, \mathrm{SB}=3.79 \mathrm{cmolc} \mathrm{dm}^{-3}, \mathrm{CEC}_{\text {effective }}=3.79 \mathrm{cmolc} \mathrm{dm}^{-3}$ $\mathrm{CEC}_{\mathrm{pH}} 7.0=6.39 \mathrm{cmolc} \mathrm{dm}^{-3}, \mathrm{~V}=59.31 \%$, and $\mathrm{OM}=23.0 \mathrm{~g} \mathrm{~kg}^{-1}$.

Tables 1 and 2 show the results of the soil + compost analyses found in each treatment at the end of the experiment.

Table 1. Results of soil fertility analyses + compost at the end of the experiment with passion fruit plants, in each treatment

\begin{tabular}{|c|c|c|c|c|c|c|c|c|c|c|c|}
\hline Treatments & $\mathrm{pH}$ & V & $\mathrm{m}$ & $\mathrm{K}^{+}$ & $\mathrm{Ca}^{2+}$ & $\mathrm{Mg}^{+}$ & $\mathrm{Al}^{3+}$ & $\mathrm{H}+\mathrm{Al}$ & SB & $\mathrm{CEC}_{\text {effective }}$ & $\mathrm{CEC}_{\mathrm{pH}}$ \\
\hline & $\mathrm{H}_{2} \mathrm{O}$ & \multicolumn{2}{|c|}{----- \% ------ } & $\mathrm{mg} \mathrm{dm}^{-3}$ & \multicolumn{7}{|c|}{ 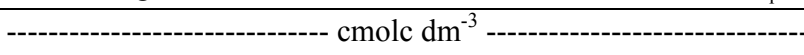 } \\
\hline $\mathrm{S}+\mathrm{C} 0 \%$ & 6.27 & 64.4 & 0.0 & 10 & 1.56 & 1.67 & 0.0 & 1.8 & 3.26 & 3.26 & 5.06 \\
\hline $\mathrm{S}+\mathrm{C} 15 \%$ & 6.82 & 88.0 & 0.0 & 28 & 3.00 & 1.33 & 0.0 & 0.6 & 4.40 & 4.4 & 5.00 \\
\hline $\mathrm{S}+\mathrm{C} 30 \%$ & 7.16 & 85.7 & 0.0 & 90 & 3.84 & 2.54 & 0.0 & 1.1 & 6.61 & 6.61 & 7.71 \\
\hline $\mathrm{S}+\mathrm{C} 45 \%$ & 7.26 & 86.2 & 0.0 & 96 & 3.85 & 2.77 & 0.0 & 1.1 & 6.87 & 6.87 & 7.97 \\
\hline $\mathrm{S}+\mathrm{C} 60 \%$ & 7.17 & 87.5 & 0.0 & 261 & 3.98 & 3.08 & 0.0 & 1.1 & 7.73 & 7.73 & 8.83 \\
\hline
\end{tabular}


Table 2. Results of soil $\mathrm{P}, \mathrm{N}$ and micronutrients analysis + compost at the end of the experiment with passion fruit plants, in each treatment

\begin{tabular}{|c|c|c|c|c|c|c|c|}
\hline Treatment & $\mathrm{P}$ & $\mathrm{N}$ & $\mathrm{Zn}$ & $\mathrm{Fe}$ & $\mathrm{Mn}$ & $\mathrm{Cu}$ & $\mathrm{B}$ \\
\hline & $\mathrm{mg} \mathrm{dm}^{-3}$ & $\mathrm{~g} \mathrm{~kg}^{-1}$ & \multicolumn{5}{|c|}{----- } \\
\hline $\mathrm{S}+\mathrm{C} 0 \%$ & 39.2 & 1.1 & 2.47 & 76.6 & 12.1 & 0.53 & 0.91 \\
\hline $\mathrm{S}+\mathrm{C} 15 \%$ & 390.4 & 1.4 & 12.42 & 20.7 & 17.8 & 0.61 & 0.27 \\
\hline $\mathrm{S}+\mathrm{C} 30 \%$ & 1228.4 & 3.2 & 23.03 & 12.7 & 22.9 & 0.66 & 0.41 \\
\hline $\mathrm{S}+\mathrm{C} 45 \%$ & 329.1 & 3.2 & 23.84 & 12.8 & 23.6 & 0.64 & 0.70 \\
\hline$S+C 60 \%$ & 1912.0 & 3.3 & 34.42 & 11.2 & 27.0 & 0.78 & 0.23 \\
\hline
\end{tabular}

The compost had $\mathrm{pH}=6.94$, Total $\mathrm{C}=109.7 \mathrm{gkg}^{-1}$, Humidity $65^{\circ} \mathrm{C}=41.69$. The materials used as organic compost and their chemical attributes are presented in Table 3.

Table 3. Analysis of the organic compost at 130 days of composting and the materials usedits preparation

\begin{tabular}{|c|c|c|c|c|c|c|c|c|c|c|c|}
\hline Material & $\mathrm{N}$ & $\mathrm{P}$ & $\mathrm{K}$ & $\mathrm{Ca}$ & $\mathrm{Mg}$ & $\mathrm{S}$ & $\mathrm{Zn}$ & $\mathrm{Fe}$ & $\mathrm{Mn}$ & $\mathrm{Cu}$ & $\mathrm{B}$ \\
\hline & \multicolumn{6}{|c|}{ 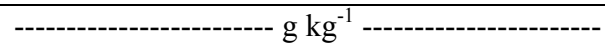 } & \multicolumn{5}{|c|}{ - } \\
\hline Finished compost & 15.2 & 12.6 & 6.3 & 52.1 & 3.6 & 7.2 & 164.0 & 2546 & 139.5 & 241.0 & 19.3 \\
\hline Duck litter & 20.8 & 19.0 & 10.9 & 51.2 & 7.0 & 10.2 & 295.0 & 4012 & 340.5 & 42.3 & 39.2 \\
\hline Poultry litter & 27.3 & 21.4 & 27.9 & 43.5 & 8.2 & 11.7 & 607.0 & 15457 & 684.0 & 297.1 & 20.9 \\
\hline Manioc bark & 10.3 & 0.6 & 7.3 & 5.05 & 0.9 & 2.3 & 22.8 & 4639.5 & 82.6 & 8.8 & 30.8 \\
\hline Manioc leaf & 36.6 & 2.0 & 12.2 & 12.0 & 4.4 & 15.3 & 61.5 & 120.8 & 52.8 & 6.5 & 52.6 \\
\hline Bean husk & 13.4 & 1.0 & 12.8 & 4.22 & 4.7 & 2.6 & 20.0 & 313.3 & 42.0 & 5.1 & 61.8 \\
\hline Rice husk & 6.4 & 1.5 & 4.6 & 2.77 & 0.8 & 2.3 & 34.9 & 6209 & 145.7 & 9.7 & 14.2 \\
\hline Corn cob & 7.4 & 0.3 & 3.4 & 0.57 & 0.5 & 1.5 & 40.4 & 189.1 & 19.9 & 2.4 & 19.5 \\
\hline
\end{tabular}

\subsection{Conducting the Experiment}

Each experimental plot consisted of one pot, with a volume of $3.6 \mathrm{dm}^{-3}$ of soil and one seedling of passion fruit. The seedlings were produced in polyethylene trays using vermiculite commercial substrate and after transplanting to the pots, the soil moisture was maintained between $60 \%$ and $80 \%$ of the total soil pore volume (VTP), using demineralized water, control performed by weighing the pots.

\subsection{Determination of Growth Parameters}

At 97 days after transplanting, the plants were harvested and evaluated for the following growth characteristics: plant height, leaf number and fresh matter mass of the whole plant. In the determination of the height of the plants, a measure tape was used with measurement made from the stem to the apex of the plant. Regarding the number of leaves, only those that had size from two centimeters in length were considered. Fresh matter mass of the plant was obtained by the sum of the fractions of the stem, leaves and roots.

Each plant was placed in separate pieces (stem, leaves and roots) in paper sacks for drying in a forced air circulation oven at $70{ }^{\circ} \mathrm{C}$ until reaching constant weight, which was obtained after approximately 72 hours. Thereafter, the leaves were processed into a Willey-type mill, equipped with a 20-mesh sieve.

\subsection{Laboratory Analysis of Plant Material}

After processing in the mill, the leaf samples were submitted to the Plant Mineral Nutrition Laboratory in the Plant Science Department at the Federal University of Viçosa for the determination of the N, P, K, Ca, Mg and S levels in passion fruit leaves.

In order to determine the levels of $\mathrm{P}, \mathrm{K}, \mathrm{Ca}, \mathrm{Mg}$ and $\mathrm{S}$, the dry and crushed plant material was submitted to nitroperchloric digestion (Johnson \& Ulrich, 1959). Phosphorus was determined by colorimetry by reduction of phosphomolybdate by vitamin C (Braga \& Defelipo, 1974); K was determined by flame photometry; Ca and Mg were quantified by atomic absorption spectrophotometry (AOAC, 1975); and S, by sulfate turbidimetry (Jackson, 1956). To determine the $\mathrm{N}$ contents, the plant material was submitted to sulfur digestion (Jackson, 1956), where the nutrient was quantified according to the method described by Bremner (1965). The macronutrient accumulation in the leaves was analyzed and calculated according to the following expression: 


$$
\mathrm{A}_{\text {macronutrient }}=\frac{\text { Leaf DM }(\mathrm{mg}) \times \text { Nutrient Concentration }\left(\mathrm{dag} \mathrm{Kg}^{-1}\right)}{100}
$$

\subsection{Experimental Design and Statistical Analysis}

The experiment was set up in a completely randomized design with five treatments and four replications, totaling 20 experimental units. The treatments consisted of five doses of the above organic compost at $0 \%, 15 \%(525 \mathrm{~g})$, $30 \%(1050 \mathrm{~g}), 45 \%(1575 \mathrm{~g})$ and $60 \%(2100 \mathrm{~g})$ proportions of the total volume of the substrate, based on the study carried out by Oliveira et al. (2004), which were applied after 130 maturation of the organic compost.

The results were submitted to analysis of variance ( $F$ test, $p<0.05$ ), adjusting regression models of the studied variables as a function of the doses of organic compost applied, considering the highest coefficients of correlation $\left(\mathrm{r}^{2}\right)$ among the significant ones, using the software Assistat.

\section{Results and Discussion}

\subsection{Biometric and Production Characteristics}

The best results for all the biometric characteristics evaluated as well as for the mass production of the fresh matter of the whole plant were observed in plants fertilized with the $60 \%$ dose of organic compost. The achieved data evidenced an increase in the mass production of the fresh matter of the yellow passion fruit plants which was proportional to the increase of the organic compoust doses, which obtained values for the fresh matter mass ranging from 82.76 to $353.52 \mathrm{~g}$ (Figure 1) for the control and $60 \%$ of the dose of the compost, respectively. Damatto Júnior et al. (2005), in a work carried out with organic fertilization in sweet passion fruit, observed the best results at the dose of $100 \%$ of the recommended one ( $5 \mathrm{~kg}$ of barn manure plant $\left.{ }^{-1}-80 \mathrm{~g} \mathrm{~N} / \mathrm{plant}\right)$. A better quality, a larger number of fruits and a greater production per plant was verified in this treatment. According to the authors, this higher production may be related to an adequate supply and availability of nutrients provided by organic fertilization, since larger doses did not provide increases in production. The same authors, using conventional fertilization recommended for the crop did not achieve good results, and this may be related to the improvement in the physical and chemical soil conditions provided by organic fertilization, which also helps to maintain the soil moisture. Hence, it is inferred that because the soil used in this work had a high sand content, despite having a good base saturation, perhaps due to liming in the area carried out by the producers not reported by them, a high amount of organic compost was necessary to improve the physical and chemical conditions of the soil, in order to meet the nutritional requirements of the crop at matter.

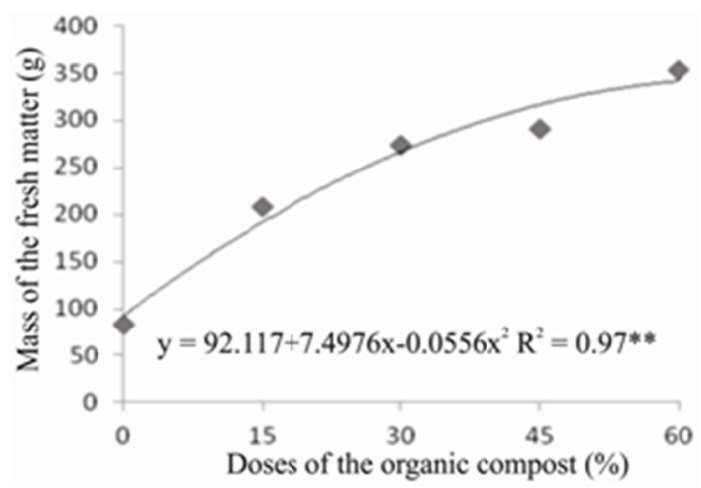

Figure 1. Mass of the fresh matter of yellow passion fruit plants as a function of doses of the organic compost in greenhouse, at 97 days after transplantating

In relation to plant height (Figure 2), the maximum estimated height was $2.70 \mathrm{~m}$ corresponding to the dose equivalent to $47.3 \%$ of organic compost. A significant increase in relation to the control $(1.45 \mathrm{~m})$ was observed. Moreover, it was verified in this treatment that at the end of the experiment, the soil had the highest base saturation (V\%), with a value equivalent to 87.5. Results were obtained by Mendonça et al. (2010) with the increase of manure doses, the aerial part had growth of $(0.42 \mathrm{~m})$ that was obtained with the bovine manure dose of $75 \%, 42$ days after planting. 


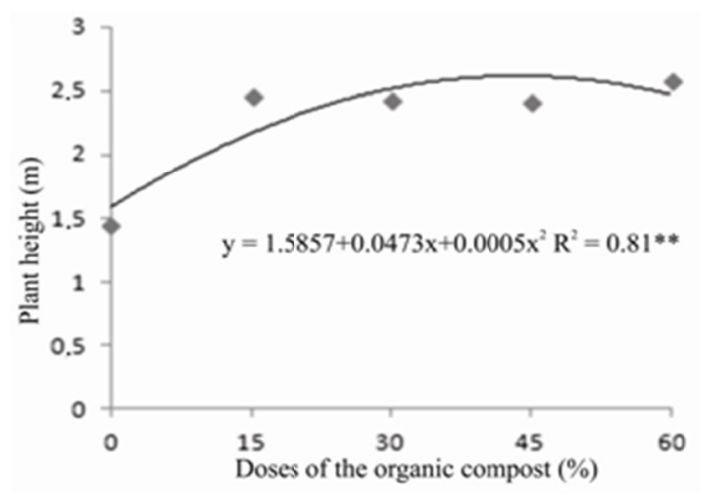

Figure 2. Height of yellow passion fruit plants using doses of $0,15,30,45$ and $60 \%$ organic compost in a greenhouse at 97 days after transplanting

Brazil and Nascimento (2010) at 50 days after experiment setting up that among the factors that showed a significant effect, phosphorus was the one that promoted the highest growth in the height of passion fruit, and verified that the maximum growth of passion fruit was obtained with the dose of $182.5 \mathrm{mg} \mathrm{dm}$, around $1.6 \mathrm{~m}$ in height. Roncatto et al. (2008) when evaluating the growth of passion fruit (Passiflora alata Dryander) propagated by cuttings and by seed under commercial orchard conditions, observed smaller values of plant height, obtaining a maximum value equivalent to $1.59 \mathrm{~m}$ in height, a value close to that observed for the control in this work $(1.45 \mathrm{~m})$. Similar results were observed by Cavalcante et al. (2002), who obtained a height equivalent to $1.76 \mathrm{~m}$ in yellow passion fruit.

When studying the behavior of yellow passion fruit in relation to irrigation water salinity and management, Cavalcante et al. (2002) obtained average values of stem diameter in the crop ranging from 15.40 to $15.65 \mathrm{~mm}$, values higher than those verified in this work, which are understandable due to different conditions of the study.

Regarding the number of leaves per plant in yellow passion fruit, a linear increase according to the doses and to the compost applied was observed. The lowest and the greatest average value reached in the experiment was 16.75 and 60.25 leaves for the control and $60 \%$ organic compost treatment, respectively (Figure 3). Except for the control, these results are greater than the maximum values observed in the work of Roncatto et al. (2008) in sweet passion fruit plants in commercial orchards (19.06 leaves). In the case of any plant, leaves are important organs, which play an active role in the process of photosynthesis (Siavoshi \& Laware, 2011).

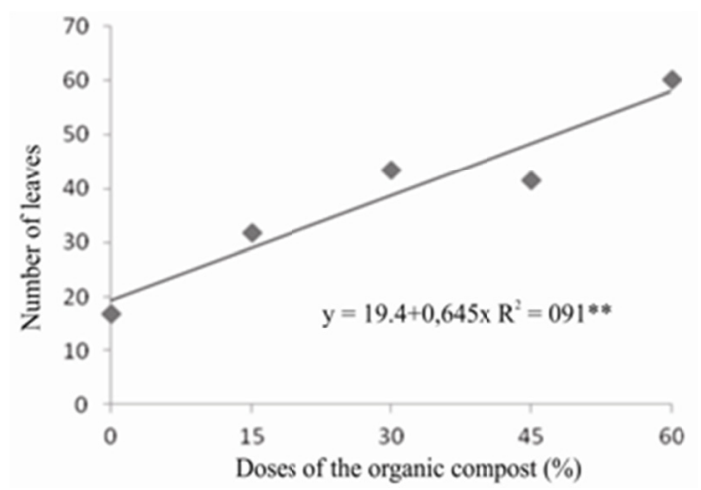

Figure 3. Number of leaves of yellow passion fruit plants as a function of doses of the organic compost, in greenhouse, at 97 days after transplantation

\subsection{Content of Macronutrient in the Leaves}

The leaf contents for the macronutrients obeyed the following order: $\mathrm{K}>\mathrm{N}>\mathrm{Ca}>\mathrm{P}>\mathrm{Mg} \geq \mathrm{S}$ (Figure 4). 


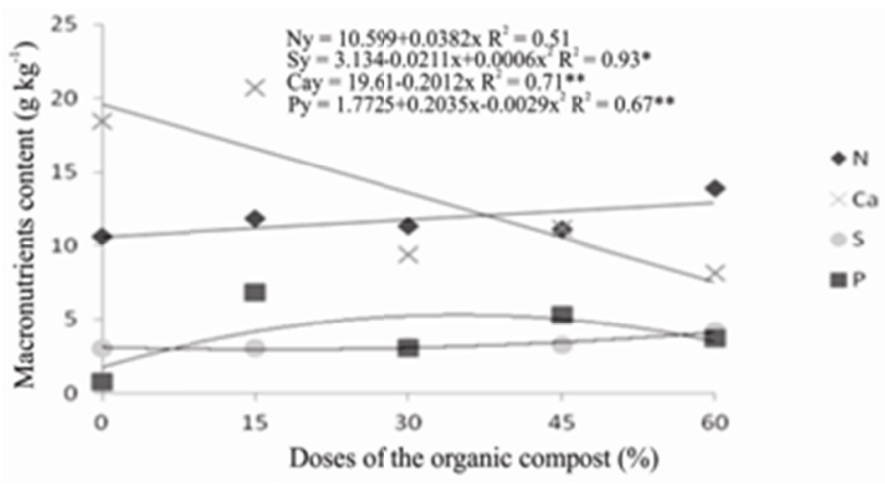

Figure 4. Macronutrients content in leaves of yellow passion fruit as a function of doses of the organic compost in greenhouse, at 97 days after transplantating

In relation to the nitrogen content in the soil (Table 2), after the plants were harvested, the content ranged from $1.1 \mathrm{~g} \mathrm{~kg}^{-1}$ (control) to $3.3 \mathrm{~g} \mathrm{~kg}^{-1}(60 \%)$. Aiyelaagbe et al. (2005) found that the ideal rate for the vegetative growth of yellow passion fruit during the juvenile and transition stages of growth was $480 \mathrm{~kg} \mathrm{~N} \mathrm{ha}^{-1}$.

In the plant, $\mathrm{N}$ was the second most required nutrient by yellow passion fruit with leaf content ranging from 10.65 to $13.88 \mathrm{mg} \mathrm{kg}^{-1}$. The values observed are smaller than the ranges verified by authors, mentioned in Table 4 in passion fruit leaves in different studies. However, it should be pointed out that in the treatments where the $45 \%$ and $60 \%$ doses of the organic compost were applied, the plants had no symptoms of deficiency, inferring that contents greater than $13 \mathrm{~g} \mathrm{~kg}^{-1}$ of $\mathrm{N}$ are suitable for the crop until approximately 100 days after transplanting. Nevertheless, at 117 days after transplanting, at full flowering plants, Freire et al., (2013) observed that the application of biofertilizer increased the $\mathrm{N}$ contents in the leaf mass of passion fruit, but with greater expressiveness in the treatments with non-saline water and mulch, ranging from 50.23 to $55.13 \mathrm{~g} \mathrm{~kg}^{-1} \mathrm{DM}$, with increases by $9.8 \%$.

Table 4. Macronutrient content ranges, in $\mathrm{g} \mathrm{kg}^{-1}$, observed in passion fruit leaves in different studies

\begin{tabular}{lllllll}
\hline Authors & $\mathrm{N}$ & $\mathrm{P}$ & $\mathrm{K}$ & $\mathrm{Ca}$ & $\mathrm{Mg}$ & $\mathrm{S}$ \\
\hline In the study (*AT) & 13.88 & 3.71 & 20.78 & 8.18 & 3.47 & 4.19 \\
Carvalho et al., 2000 & $34.7-49.8$ & $2.31-3.43$ & $23.5-35.5$ & $10.6-15.1$ & $2.13-3.62$ & $3.19-4.33$ \\
Carvalho et al., 2002 & $34.7-58.0$ & $2.31-3.85$ & $24.1-38.0$ & $6.13-14.4$ & $2.13-4.28$ & $3.11-4.64$ \\
Alves, 2003 & $44.3-53.5$ & $2.46-3.25$ & $18.4-29.3$ & $9.6-13.8$ & $2,68-3.92$ & $2.91-4.82$ \\
Fontes, 2005 & $48.8-58.7$ & $2.47-2.96$ & $17.3-20.9$ & $9.91-13.1$ & $3.34-4.04$ & $3.96-5.07$ \\
Martins, 2009 & $32.7-48.9$ & $2.19-2.93$ & $29.8-33.4$ & $9.51-19.34$ & $3.65-6.46$ & $2.89-5.65$ \\
Moraes et al., 2011 & $31.3-36.5$ & $2.14-3.01$ & $26.8-44.7$ & $3.88-6.47$ & $2.55-3.55$ & - \\
\hline
\end{tabular}

Note. ${ }^{*}$ Where: $\mathrm{AT}=$ average value in the best treatment $(60 \%$ organic compost).

According to Cruz et al. (2006), nitrogen deficiency can affect the growth and development of plants, particularly because it is a constituent of proteins and chlorophylls, so these plants may not express their full potential, resulting in significant reduction in the formation rate and leaf expansion.

In the soil, only the phosphorus contents varied from 39.2 to $1912 \mathrm{mg} \mathrm{dm}^{-3}$ in the control treatments and $60 \%$ of the organic compost (Table 2). It should be highlighted the importance of the organic matter for this element in the soil, emphasizing that the organic compost increased the content of this element by 10 times at least and by 49 times, at the maximum, in the soil. The reason for this event may be related to the presence of humic substances (HSs) in organic matter, which in addition to providing greater stability to the soil, improving its structure, increasing crop productivity and quality, increasing surface area, the CEC and the buffer effect, giving greater stability to the soil, also provide the adsorbed phosphorus in the clay fraction (Moreira \& Siqueira, 2006) However, the greater content of the element in the soil did not mean greater absorption by the plants.

The leaf content of P ranged from 0.81 to $6.82 \mathrm{~g} \mathrm{~kg}^{-1}$, exceeding the values achieved by Fontes (2005), Martins (2009) and Moraes et al. (2011) in passion fruit in some treatments. The contents of phosphorus in leaves of the passion fruit had similar behavior to the magnesium content, with the highest values corresponding to the 
treatments with the $15 \%(525 \mathrm{~g} / \mathrm{pot})$ dose of the organic compost. The maximum estimated dose of the compost was $35.08 \%$, obtaining a phosphorus content of $5.34 \mathrm{~g} \mathrm{~kg}^{-1}$ of P in the leaves. It is important to highlight that the application of the organic compost raised the phosphorus content in the leaves by a minimum of 3.8 times and a maximum of 8.4 times in relation to the control, making it clear the importance of organic matter as a source of phosphorus and its contribution in the availability and dynamics of this element.

The potassium content in the soil ranged from 10 to $261 \mathrm{mg} \mathrm{dm}^{-3}$ (Table 1), showing an increase in the element proportional to the applied doses of the organic compost, which increased by 2.8 to 26.1 times in relation to the control.

Regarding potassium in the plant, this nutrient was the most required by the crop. The amplitude of $\mathrm{K}$ contents ranged from 17.88 to $20.86 \mathrm{~g} \mathrm{~kg}^{-1}$ in the leaves of yellow passion fruit. Freire et al. (2013) observed potassium values varying from $17.5 \mathrm{~g} \mathrm{~kg}^{-1}$ among plants in the saline water treatment, without biofertilizer and without soil cover and $25.8 \mathrm{~g} \mathrm{~kg}^{-1} \mathrm{DM}$ in plants treated with non-saline water, with biofertilizer and mulch.

Moraes et al. (2011) report that potassium is required in large quantities by passion fruit, a fact also observed in this work. According to Freitas et al. (2011) the deficiency of this nutrient causes delay in flowering, reduction in fruit size and leaf area, consequently affecting photosynthesis and solids content in fruits, leaf fall and floral buds. The need for potassium by this crop needs to be determined and/or adjusted according to the cultivation and management system, considering that the recommendations of conventional fertilization with potassium in Brazil found in the literature are largely variable, from 50 to $530 \mathrm{~kg}$ of $\mathrm{K}_{2} \mathrm{O} \mathrm{ha}^{-1}$ year (Borges et al., 2002). With reference to the evaluation of the nutritional status of yellow passion fruit plants by means of foliar diagnosis, Sousa et al. (2008) verified that, even with the frequent application of potassium, the plants presented deficiency of this element, which according to the authors, can be attributed to plant age, leaf collection period, emission of flowers, tendrils, flower buds and fruit development. According to Freitas et al. (2011) and Araújo et al., (2005), potassium is most required by the plants during fruiting, formation and maturation of the fruits, since this is the most important nutrient for passion fruit at this phase.

At all dosages, the leaf contents were below the appropriate range for the crop, that is, between 26.1 and $45.1 \mathrm{~g}$ $\mathrm{kg}^{-1}$, considered by Malavolta et al. (1997). The results are similar to the results found by Martins (2009) and Morais et al. (2011). However, it is worth mentioning that even below the optimal range, the plants did not present symptoms of deficiency.

The leaf content of calcium ranged from $8.18(60 \%)$ to $20.71 \mathrm{~g} \mathrm{~kg}^{-1}(15 \%)$ with an average content equivalent to $13.57 \mathrm{~g} \mathrm{~kg}^{-1}$. The values were below those observed by Sousa et al., (2008) and close to the values found by Martins (2009) and above those observed by Morais et al. (2011). In the soil, the calcium content varied from 1.65 to $3.98 \mathrm{mg} \mathrm{dm}^{-3}$, for the control and $60 \%$ organic compost treatment, respectively (Table 1).

In the soil, the magnesium content varied from 1.67 to $3.08 \mathrm{mg} \mathrm{dm}^{-3}$, and the organic compost increased by up to 1.8 times the soil nutrient content in relation to the control (Table 1). Magnesium was the less required nutrient by the crop, with foliar content ranging from 2.94 to $4.07 \mathrm{~g} \mathrm{~kg}^{-1}$ remaining within the optimal level and equivalent to the levels set by Fontes (2005) and Alves (2003).

Despite being required in small quantities, sulfur is probably the least commonly used macronutrient in fertilization. However, many important crops require it in amounts greater than or equal to that of phosphorus (Mello et al., 1984). It was evidenced in this study where the sulfur content in leaves ranged from 3.07 to $4.19 \mathrm{~g}$ $\mathrm{kg}^{-1}$, that the amount required by the culture was equivalent to that required by magnesium. The maximum estimated content of sulfur was $2.94 \mathrm{~g} \mathrm{~kg}^{-1}$, which was displayed when the equivalent dose to $17.58 \%$ of the organic compost was applied. Plants rely on $\mathrm{S}$ to perform photosynthesis, respiration, synthesis of fats and proteins and symbiotic fixation of nitrogen (Corsi et al., 2007). Garcia et al. (2011) observed that for the initial development of vigorous yellow passion fruit seedlings in the nursery, $0.38 \mathrm{~kg} \mathrm{~m}^{-3}$ of elemental sulfur should be used in the substrate. In addition, doses above this value inhibit the growth of yellow passion fruit seedlings. All sulfur contents are within the range obtained by Martins (2009), who observed greater sulfur contents of $5.65 \mathrm{~g}$ $\mathrm{kg}^{-1}$ in the dry matter in plants submitted to fertilization with bovine manure plus ammonium sulfate and by the other authors mentioned in Table 4, in different studies with passion fruit.

\subsection{Macronutrient Accumulation in Leaves}

The accumulation of macronutrients in the yellow passion fruit leaves followed the order: $\mathrm{K}>\mathrm{N}>\mathrm{Ca}>\mathrm{P}>\mathrm{Mg}$ $\geq \mathrm{S}$ (Figure 6). Cruz et al. (2006) observed that the content of macronutrients in passion fruit seedlings, grown for 50 days on inert substrate added with nutrient solution as a function of salinity, at the $\mathrm{NaCl}$ level equal to $100 \mathrm{mmol} \mathrm{L}^{-1}$, obeyed the following order: $\mathrm{K}>\mathrm{Ca}>\mathrm{P}>\mathrm{Mg}>\mathrm{S}$. However, the same authors observed that in the 
absence of $\mathrm{NaCl}$, the order in the accumulation was $\mathrm{K}>\mathrm{N}>\mathrm{Ca}>\mathrm{P}>\mathrm{Mg}>\mathrm{S}$, agreeing with the results found in this work. Júnior and Cuzzuol (2009), when analyzing the mineral composition of Passiflora mucronata observed the following decreasing order of macronutrients: $\mathrm{Ca}>\mathrm{N}>\mathrm{K}>\mathrm{S}>\mathrm{Mg}>\mathrm{P}$, also showing that larger accumulations of macro and micronutrients in the leaf occur in relation to the concentration of nutrients available in the soil.

Prado et al. (2005) studying the effect of potassium application on substrate of the dystrophic Red Latosol obtained the following order of macronutrient accumulation in the aerial part of yellow passion fruit seedlings at 60 days after sowing: $\mathrm{N}>\mathrm{K}>\mathrm{Ca}>\mathrm{S}>\mathrm{P}>\mathrm{Mg}$.

It is pertinent to add that the accumulations of macronutrients observed in the present study showed some variations in relation to other studies. It should be noted that such differences are possibly to occur due to the genotype factor, the distinct edaphoclimatic conditions, the fruit load of the plants, among others (Prado et al., 2005), and also to different collection times, assessed varieties and types of sampling (Chaves et al., 2009).

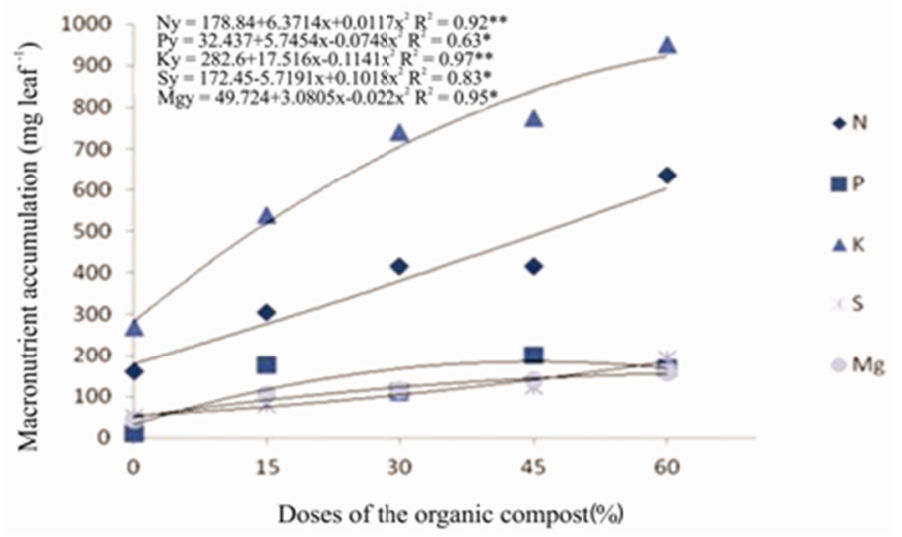

Figure 6. Macronutrient accumulation in passion flower leaves according to the doses of the organic compost in greenhouse at 97 days after transplanting

\section{Conclusion}

Yellow passion fruit mainly requires nutrients: $\mathrm{K}, \mathrm{N}, \mathrm{Ca}, \mathrm{P}$. The sequence of accumulation of macronutrients in the leaves of the plant is $\mathrm{K}>\mathrm{N}>\mathrm{Ca}>\mathrm{P}>\mathrm{Mg} \geq \mathrm{S}$. Yellow passion fruit responded to fertilization with organic compost, obtaining the best dose results with $60 \%$ of the compound.

\section{References}

Aiyelaagbe. O. O., Fagbayide. J. A., \& Makinde. A. I. (2005). Effects of N fertilization on the vegetative growth of passion frui (Passiflora edulis f. flavicarpa) seedlings. Journal of Food, Agriculture \& Environment, 3, 62-64.

Alves, G. da S. (2003). Resposta do maracujazeiro amarelo, híbrido composto 273/277+275, à adubação nitrogenada (p. 36). Trabalho de Conclusão de Curso, Centro de Ciências Agrárias, Universidade Federal da Paraíba, Areia, Brazil.

Araújo, R. C., Bruckner, C. H., Martinez, H. E. P., Salomão, L. C. C., Venegas, V. H. A., Dias, J. M. M., ... Souza, J. A. de. (2005). Crescimento e produção do maracujazeiro-amarelo em resposta à nutrição potássica. Revista Brasileira de Fruticultura, 27, 128-131. https://doi.org/10.1590/S0100-29452005000100034

AOAC (Association of Official Analytical Chemists). (1975). Official methods of analysis (12th ed., p. 1094). Washington, USA.

Borges, A. L., Caldas, R. C., Lima, A. de A., \& Almeida, I. E. de. (2002). Efeito das doses de NPK sobre os teores de nutrientes nas folhas e no solo, e na produtividade do maracujazeiro amarelo. Revista Brasileira de Fruticultura, 24, 208-213. https://doi.org/10.1590/S0100-29452002000100045

Braga, J. M., \& Defelipo, B. V. (1974). Determinação espectrofotométrica de P em extratos de solo e material vegetal. Revista Ceres, 21, 73-85. 
Brasil, E. C., \& Nascimento, E. V. S. do. (2010). Influência de calcário e fósforo no desenvolvimento e produção de variedades de maracujazeiro-amarelo. Revista Brasileira de Fruticultura, 32(3), 892-902. https://doi.org/ 10.1590/S0100-29452010005000092

Bremner, J. M. (1965). Total nitrogen. In C. A. Black (Ed.), Methods of soil analysis (pp. 1149-1178). Madison, American Society of Agronomy.

Cavalcante, L. F., Andrade, R., Filho, J. C. F., Oliveira, F. A. de., Lima, E. M. de., \& Cavalvante, I. H. L. (2002). Resposta do maracujazeiro amarelo (Passiflora edullis $f$. flavicarpa Deg.) ao manejo e salinidade da água de irrigação. Agropecuária Técnica, 23(1/2), 27-33.

Chaves, L. H. G., Cabral, P. C. P., Junior, G. B., \& Lacerda, R. D. de (2009). Efeito de zinco e cobre no estado nutricional da mamoneira. BRS 188 Paraguaçu. Revista Caatinga, 22(4), 129-135.

Corsi, M., Goulart, R. C. D., \& Andreucci, M. P. (2007). Nitrogênio e enxofre em pastagens. In T. Yamada, S. R. Stipp, A. G. C. Vitti (Eds.), Nitrogênio e enxofre na agricultura brasileira (pp. 487-517). Piracicaba, IPNI, Brasil.

Cruz, J. L., Pelacani, C. R., Coelho, E. F., Caldas, R. C., Almeida, A. Q. de., \& Queiroz, J. R. de. (2006). Influência da salinidade sobre o crescimento, absorção e distribuição de sódio, cloro e macronutrientes em plântulas de maracujazeiro amarelo. Bragantia, 65(2), 275-284. https://doi.org/10.1590/S0006-87052006 000200009

Cunha, T. J. F., Mendes, A. M. S., \& Giongo, V. (2015). Matéria orgânica do solo. Embrapa Semiárido (Technical Release).

Damatto Junior, E. R., Leonel, S., \& Pedroso, C. J. (2005). Adubação orgânica na produção e qualidade de frutos de Maracujá-doce. Revista Brasileiro de Fruticultura, 27(1), 188-190. https://doi.org/10.1590/S0100-2945 2005000100051

Embrapa (Empresa Brasileira de Pesquisa Agropecuária). (1997). Manual de métodos de análise de solos (2nd ed., p. 212). Centro Nacional de Pesquisa de Solos, Rio de Janeiro, Brazil.

Faleiro, F. G., \& Junqueira, N. T. V. (2016). Maracujá: O produtor pergunta, a Embrapa responde. Brasília, DF: Embrapa.

Fontes, P. S. F. (2005). Eficiência da fertirrigação com nitrogênio e avaliação do estado nutricional do maracujazeiro amarelo utilizando o DRIS (Thesis, Universidade Estadual do Norte Fluminense Darcy Ribeiro, Campos dos Goytacazes, Brazil).

Freire, J. L. O., C, L. F., Nascimento, R., \& Rebequi, A. M. (2013). Teores de clorofila e composição mineral foliar do maracujazeiro amarelo irrigado com águas salinas e biofertilizante. Revista de Ciências Agrárias, $36,57-70$.

Freitas, M. S. M., Monnerat, P. H., Carvalho, A. J. C. de., \& Vasconcellos, M. A. da S. (2011). Sintomas visuais de deficiência de macronutrientes e boro em maracujazeiro-doce. Revista Brasileira de Fruticultura, 33(4), 1329-1341. https://doi.org/10.1590/S0100-29452011000400034

Garcia, K. G. V., Silva, C. P. DA., Silva, R. M. da., Mendonça, V., \& Tosta, M. da. S. (2011). Desenvolvimento inicial de mudas de maracujazeiro amarelo em função de doses crescentes de enxofre. Revista Verde, 6(2), 131-134.

Gondim, S. C., Cavalcante, L. F., Campos, V. B., Mesquita, E. F., \& Gondim, P. C. (2009). Produção e composição foliar do maracujazeiro amarelo sob lâminas de irrigação. Revista Caatinga, 22(4), 100-10.

IBGE (Instituto Brasileiro De Geografia e Estatística). (2017). Retrieved from http://www.sidra.ibge.gov.br

Jackson, M. L. (1958). Soil chemical analysis (p. 498). New Jersey, Prentice Hall.

Johnson, C. M., \& Ulrich, A. (1959). Analytical methods for use in plants analyses (Vol. 766, pp. 32-33). Los Angeles, University of California.

Junior, J. L., \& Cuzzuol, G. R. F. (2009). Caracterização de solos de duas formações de restinga e sua influência na constituição química foliar de Passiflora mucronata Lam. (Passifloraceae) e Canavalia rosea (Sw.) DC. (Fabaceae). Acta Botânica Brasílica, 23(1), 239-246. https://doi.org/10.1590/S0102-33062009000100025

Malavolta, E., Vitti, G. C., \& Oliveira, S. A. (1997). Assessment of Nutritional Status of Plants: Principles and Applications (2nd ed. p. 319). Potafos, Piracicaba, Brazil. 
Martins, C. M. (2009). Crescimento, nutrientes e teor de vitexina em Passifloraceas em função de adubação nitrogenada (Thesis, Universidade Estadual do Norte Fluminense Darcy Ribeiro, Campos dos Goytacazes, Brazil).

Meletti, L. M. M. (2011). Avanços na cultura do maracujá no Brasil. Revista Brasileira de Fruticultura, 33(1), 83-91. https://doi.org/10.1590/S0100-29452011000500012

Mello, F. A. F., Brasil Sobrinho, M. O. C., Arzolla, S., Silveira, R. I., Cobra Netto, A., \& Kiehl, J. C. (1984). Fertilidade do Solo (2nd ed., p. 400). Nobel, São Paulo, Brasil.

Mendonça, J. D. J. de., Fernandes, P. L. O., Morais, F. A. de., Costa, M. E., Melo, I. G. C., Goes, G. B. de., \& Veras, A. R. R. (2010). Doses de esterco bovino na produção de mudas de pinheira. XXI Congresso Brasileiro De Fruticultura, Natal, RN. Anais... Natal, RN.

Menzel, C. M., Haydon, G. E., Doogan, V. J., \& Simpson, D. R. (1993). New standard leaf nutrient concentrations for passion fruit based on seasonal phenology and leaf composition. Journal of Horticultural Science, 68, 215-230. https://doi.org/10.1080/00221589.1993.11516346

Moraes, J. C. B. de, Salcedo, I. H., \& Sousa, V. F. de. (2011). Doses de potássio por gotejamento no estado nutricional do maracujazeiro. Revista Brasileira de Engenharia Agrícola Ambiental, 15(8), 763-770. https://doi.org/10.1590/S1415-43662011000800001

Moreira, F. M. S., \& Siqueira, J. O. (2006). Microbiologia e bioquímica do solo (2nd ed., p. 729). UFLA, Lavras, Brazil.

Oliveira, R. F. de, Teixeira, B. L., \& Germano, V. L. C. (2004). Composto orgânico de Lixo e Adubos Orgânicos Tradicionais na Produção de Matéria Seca de Milho e na Fertilidade do solo (p. 18). EMBRAPA, Belém, Brazil.

Pires, A. A., Monnerat, P. H., Marciano, C. R., Pinho, L. G. da. R., Zampirolli, P.A., Rosa, R. C. C., \& Muniz, R. A. (2008). Efeito da adubação alternativa do maracujazeiro amarelo nas características químicas e físicas do solo. Revista Brasileira de Ciência do Solo, 32, 1997-2005. https://doi.org/10.1590/S0100-06832008000 500021

Prado, R. M., Natale, W., Braghirolli, L. F., \& Ragonha, E. (2005). Estado nutricional do maracujazeiro-amarelo "fb 200" sobre cinco porta-enxertos, cultivado em um latossolo vermelho distrófico. Revista Agricultura, 80(3), 388-399.

Prado. R. de. M., Braghirolli. L. F., Natale. W., Corrêa, M. C. de. M., \& Almeida E. V. de. (2004). Aplicação de potássio no estado nutricional e na produção de matéria seca de mudas de maracujazeiro amarelo, Revista Brasileira de Fruticultura, 26(2), 295-299. https://doi.org/10.1590/S0100-29452004000200028

Roncatto, G., Filho G. C. N., Ruggiero, C., Oliveira, J. C. de., \& Martins, A. B. G. (2008). Avaliação do desenvolvimento de maracujá-doce (Passiflora alata Dryander) propagado por estaquia e por semente em condições de pomar comercial. Revista Brasileira de Fruticultura, 30(3), 754-758. https://doi.org/10.1590/ S0100-29452008000300032

Siavoshi, M., Nasiri, A., \& Laware, S. L. (2011). Effect of Organic Fertilizer on Growth and Yield Components in Rice (Oryza sativa L.). Journal of Agricultural Science, 3(3), 217-224. https://doi.org/10.5539/ jas.v3n3p217

Sousa, V. F. de., Folegatti, M. V., Frizzone, J. A., Dias, T. J., Alburquerque Junior, B. S., \& Batista, E. C. (2008) Níveis de irrigação e doses de potássio sobre os teores foliares de nutrientes do maracujazeiro amarelo. Revista Brasileira de Engenharia Agrícola e Ambiental, 12(1), 41-46. https://doi.org/10.1590/S1415-4366 2008000100006

Tenório, E. (2016). Cultivo do maracujá é alternativa de aumento de renda para a agricultura familiar. Retrieved from https://portal.to.gov.br/noticia/2016/7/13/cultivo-do-maracuja-e-alternativa-de-aumento-de-renda-para -a-agricultura-familiar

\section{Copyrights}

Copyright for this article is retained by the author(s), with first publication rights granted to the journal.

This is an open-access article distributed under the terms and conditions of the Creative Commons Attribution license (http://creativecommons.org/licenses/by/4.0/). 